\title{
Kommentaar op Jakobus in Afrikaans
}

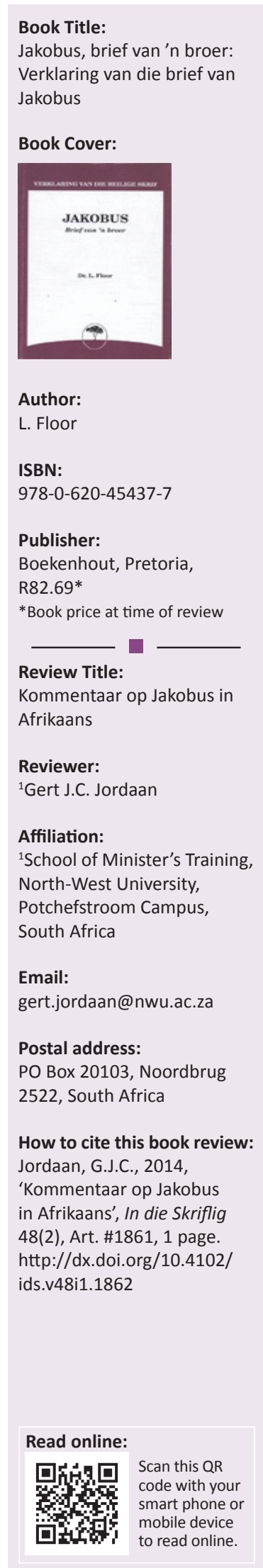

Hierdie boek is 'n Afrikaanse vertaling van Jakobus, brief van een broeder wat in 1992 verskyn het as deel van die Derde Serie van die bekende Nederlandse kommentaarreeks, Commentaar op het Nieuwe Testament. In die Derde Serie word op die hoog aangeskrewe en gewaardeerde eerste en tweede reekse voortgebou wat vroeër in die twintigste eeu gepubliseer is. Hierdie nuwe reeks is ' $n$ aanwins in die opsig dat nuwe insigte wat sedert die verskyning van die vorige reeks bygekom het, hierby ingewerk is. Onder meer is met goeie vrug gebruik gemaak van die resultate van sosio(kultuur)-historiese navorsing en stilistiese insigte vanuit literêre oorwegings wat aan die einde van die twintigste eeu in teologiese kringe heelwat aandag ontvang het. Daar word ook rekening gehou met nuwer ontwikkelings op die terrein van tekskritiek.

In hierdie aangeleenthede is Jakobus, brief van ' $n$ broer 'n sprekende voorbeeld.

Nuwe eksegetiese insigte en beskouings word regdeur die boek na vore gebring. Soms word die nuwe standpunte kortliks aan die orde gestel en aangetoon in watter opsigte dit van die ouer standpunte verskil. So word op bladsy 107 daarop gewys dat die beskouing van Dibelius, naamlik dat Jakobus se brief inderwaarheid slegs 'n reeks moraalspreuke is wat Griekse en Joodse lewenswysheid bevat, sedert die twintigerjare van die vorige eeu die hantering van die Jakobusbrief tot 'n groot mate gedomineer het. Sedert die tagtigerjare het 'n nuwe rigting (met literatuurverwysings) egter die deurslag begin gee, naamlik dat Jakobus 'n werklike brief met 'n besliste eie samehangende gedagtestruktuur is, gerig op die problematiek van sy tyd, net soos die ander briewe van die Nuwe Testament. Soms vermeld Floor egter die nuwer insigte sonder om dit verder te bespreek en bied dan slegs 'n uitgebreide literatuurlys oor die onderwerp (bv. bl. 128).

Inligting uit buite-Bybelse bronne word op 'n verantwoordelike wyse in die kommentaar verreken. Op bladsy 22 skryf Floor byvoorbeeld met betrekking tot die eerste lesers van die brief: " $n$ Aantal leidrade dui ook daarop dat die eerste lesers in die Palestyns-Siriese gebied gesoek moet word.' As voorbeeld van so 'n leidraad verwys hy dan na die derde-eeuse geskrif, De Virginitate, wat in Palestina geskryf is en waarin die brief van Jakobus aangehaal word. Op blasdy 151 bespreek hy die begrip volmaaktheid in Jakobus 3:2 met inagneming van die beskouings van onder meer Aristoteles, Aeschylos en die Rabbyne, asook die woorde waarmee daar in die Septuagint na volmaaktheid verwys word. Veral inligting vanuit die Joodse geskrifte geniet in die kommentaar besondere aandag.

Waar variante lesings in verskillende uitgawes van die teks van die Griekse Nuwe Testament ter sake is, ontvang dit die nodige aandag - ook met verwysing na die betekenisverskille wat sodanige variante lesings tot gevolg sou hê. Dit word byvoorbeeld op bladsy 202 gedoen met betrekking tot die variante lesings by Jakobus 4:14 in die nuwer uitgawes soos die UBS ${ }^{3}$-uitgawe van 1975 en die Greek New Testament according to the majority text van Hodges en Farstad (1982). Waar nodig, word ook aan variante lesings van afsonderlike manuskripte van die Griekse Nuwe Testament aandag gegee soos die geval is by die bespreking van Jakobus 4:15 op bladsy 203.

'n Ontwikkeling waarin hierdie kommentaar deur prof. Floor in die besonder uitmunt, is die aandag wat aan die samehang van gedagtepatrone in die brief gegee word. Talle voorbeelde van skematiese voorstellings van die gedagte-opbou word op die bladsye van hierdie kommentaar aangetref. 'n Mooi voorbeeld is op bladsy 75, waar die kunstige gestruktureerdheid van Jakobus 1:9 beskryf word. Eers word ' $n$ kort uiteensetting van die parallelismus membrorum in die vers gegee, waarna 'n skematiese voorstelling van die chiastiese stylfiguur wat daarin voorkom aangebied word. Hierdie uiteensettings is egter nie net kosmeties van aard nie, maar word doeltreffend aangewend as bevestigende aanwysings van ooreenkomste, kontraste en beklemtonings wat die skrywer daardeur in die teks na vore bring.

In die geheel beskou, is hierdie kommentaar op die Jakobusbrief ' $n$ waardige opvolger van die kommentare van die vorige reekse wat onderskeidelik in 1927 en 1955 deur F.W. Grosheide geskryf is. Met die vertaling in Afrikaans word hierdie deeglik begronde kommentaar van die Derde Serie ook in maklik leesbare taal binne die bereik van die gemiddelde Afrikaanse leser gestel. Ek kan die boek van harte aanbeveel, nie net vir predikante nie, maar ook vir ernstige Bybelstudente.

Copyright: (c) 2014. The Authors. Licensee: AOSIS OpenJournals. This work is licensed under the Creative Commons Attribution License. 